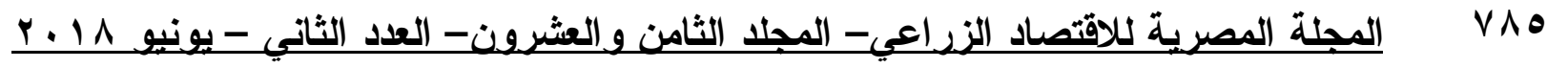

\title{
An Economic Study of Egypt's Agricultural Trade in the Context of Nile Basin's Initiative
}

\author{
Esam Mohamed Zaki, \\ Agricultural Economics Research Institute
}

\section{Introduction}

Recently, interest in enhancing trade relations between Egypt and African countries has been renewed, besides upgrading economic cooperation mechanisms between the two parties given the fact that African countries are considered an important hub to Egypt's economic and trade policies hubs. Such orientation has been reflected in the Government of Egypt's tendency towards developing perceptions and coordinating efforts in this direction, especially in light of contemporary local, regional and global changes, which have necessitated the pursuit of closer trade between Egypt and countries of the African continent in general, and Nile Basin countries in particular, an issue of strategic importance to Egypt's national water security system that calls for dealing with these countries in the framework of a comprehensive strategic perception that depends on linking the common interests of the Nile Basin countries together, either in the form of bilateral or multilateral agreements, such as the Nile Basin Initiative, which was signed by the ten Nile Basin countries in February 1999 (Sudan, Ethiopia, Democratic Republic of the Congo, Uganda, Kenya, Egypt, Rwanda, Burundi, Tanzania, Eritrea) with the aim of strengthening regional cooperation bonds (economic and social) between such countries in order to accelerate economic development wheels within a balanced framework, and to increase the volume of intra-trade and joint investments between member countries. Hence, the importance of economic integration and cooperation among Nile Basin countries emerges, which a goal that can be achieved by increasing the effectiveness of intra-trade between member countries. However, it is necessary to identify changes in the economies of such countries in general, and the volume of agricultural trade in particular as a result of implementing such agreements. It is worth mentioning that, in 2016, total value of trade between Egypt and Nile Basin countries reached around US\$ 1.45 billion, while the value of agricultural trade reached around US\$ 1.38 billion ${ }^{(1)}$.

\section{Research Problem}

The problem this research aims to study is that, despite the large number of countries joining the Nile Basin Initiative, and the numerous products and commodities these countries produce, whether raw, intermediate, or even final, reality shows that trade between Egypt and Nile Basin countries is still weak, where total and agricultural trade with Nile Basin countries accounted for $1.25 \%$ and $5.99 \%$ of Egypt's total and agricultural trade over the period 1994-2016, respectively. Such low figures do not fulfill Egypt's aspirations towards strengthening political and economic relations with African countries, which requires exerting more efforts to increase the terms of trade and common interests between the concerned parties. 


\section{Research Objective}

The main objective this research aims o achieve is to study evolution in total and agricultural trade between Egypt and Nile Basin Countries, geographic distribution and commodity concentration of traded goods, to measure the degree of similarity and compatibility between Egypt and Nile Basin Countries' export structure, and to measure Nile Basin countries markets' competence to absorb Egyptian exports.

\section{Sources of Data}

The research relied on secondary data published by the Central Agency for Public Mobilization and Statistic, Trade Statistics for International business development Database (UN Comtrade), in addition to a number of research papers, theses, studies and scientific books relevant to the research subject.

\section{Methodology}

Both descriptive and quantitative analysis methods have been applied, including:

1. Simple Regression Analysis: to estimate growth in foreign trade indicators and trade exchange between Egypt and Nile Basin Countries:

$$
\hat{\mathrm{Y}}_{\mathrm{i}}=\alpha+\beta \mathrm{x}_{\mathrm{i}} \text {, }
$$

Where,

$\hat{Y}_{i}$ is the estimated value of variable $i$; $\alpha$ is the constant, $\beta$ is coefficient, and $x_{i}$ is the time variable.

2. Non-stability Coefficient: to assess the degree of stability in trade exchange between Egypt and Nile Basin Countries:

$$
\text { Non-stability Coefficient }=\frac{\left|y_{i}-\hat{y}_{i}\right|}{\hat{y}_{i}} * 100
$$

Where,

$y_{z}:$ is the actual value of exports/or Imports variable;

$\hat{y}_{i}$ : Is estimated value of exports/or Imports variable.

3. Gini-Hirschman Coefficient: is a coefficient of geographic distribution/concentration of economic activity. It is used to calculate the degree of geographic distribution and commodity concentration of foreign trade and trade in agricultural commodities with the Nile Basin Counties.

$$
\text { Gini Hirschman Coefficient }=\sqrt{\sum\left(\frac{x_{i j}}{x_{i v}}\right)^{2}} * 100
$$

Where,

$x_{i j}$ : is the value of exports/imports to/from the country/commodity $\mathrm{i}$ to/from country j.

$x_{i w}$ : the total value of exports/imports of the country/commodity $\mathrm{i}$ to/from the country w. 
4. Export Similarity Index: is used to measure of the extent to which Egypt's export structure is similar or dissimilar to that of Nile Basin Countries for assessing potentials of creating trade between the two parties.

$$
\text { Exports Similarity, } \mathrm{S}(a b, c)=\left[\sum \operatorname{Min}\left\{X_{i}(a c), X_{i}(b c)\right\} * 100\right]
$$

Where,

$X_{i}(a c)$ : is the share of commodity $\mathrm{i}$ in a's exports to $\mathrm{c}$.

$X_{i}(b c)$ : is the share of commodity $i$ in b's exports to $\mathrm{c}$.

5. Trade Compatibility Index: is used to measure compatibility between Egypt's and Nile Basin Countries' exports/imports to assess potentials for transformation of trade between the two parties. It ranges between 0 and 1 . The higher the value of the index, the higher the degree of compatibility.

$$
\text { Trade Compatibility }=1-\left\{\frac{\left(\sum\left|M_{b i}-X_{a i}\right|\right)}{2}\right\}
$$

Where,

$\mathrm{M}_{\mathrm{bi}}$ : is the share of commodity $\mathrm{i}$ in b's agricultural imports.

$\mathrm{X}_{\mathrm{ai}}$ : is the share of commodity $\mathrm{i}$ in a's agricultural exports.

6. Compassing Competence: is used to measure Nile Basin Countries' competence to absorb Egyptian exports.

$$
\text { Compassing Competence }=\frac{\frac{E x}{\operatorname{Im}}}{\operatorname{Min}\{\operatorname{Im} / E x\}} * 100
$$

Where,

Ex: Egypt's exports to NB Countries.

Im: NB Countries' imports from the world.

\section{Results and Discussion}

\section{Relative Importance of Indicators on Egypt's Total Trade with Nile Basin Countries}

Results in Table (1) reveal that relative importance of the value of Egypt's total trade with Nile Basin Countries over the period 1994-2016 averages to $1.25 \%$, ranging between a minimum of $0.66 \%$ in 1998 and a maximum of $1.82 \%$ in 2016 . Results of applying simple regression analysis to the relative importance of the value of Egypt's total trade with Nile Basin Countries, presented in Table (2), reveal that it followed a statistically significant increasing trend, at an annual rate of $0.04 \%$ and an annual growth rate of $3.27 \%$. Non-stability Coefficient reached $15.8 \%$, indicating stability in the relative importance of the value under study.

As for the relative importance of the value of Egypt's total exports to Nile Basin Countries over the period 1994-2016, results presented in Table (1) reveal that the relative importance of the value of Egypt's total exports to Nile Basin Countries reached an average of $2.33 \%$, ranging between a minimum of $0.75 \%$ in 1996 and a maximum of $5.03 \%$ in 2015 . Regression analysis results reveal that it followed a statistically significant increasing trend, at an annual rate of $0.19 \%$ representing $8.3 \%$ 
of the period's average, as shown in Table (2). Non-stability Coefficient reached $37.03 \%$, indicating stability in the relative importance of the value under study.

Turning to imports, results presented in Table (1) reveal that the relative importance of the value of Egypt's total imports from Nile Basin Countries over the period 1994-2016 ranges between a minimum of $0.38 \%$ in 2007 and a maximum of $1.67 \%$ in 2002 , recording an average of $0.77 \%$. Regression analysis results reveal that the computed relative importance followed a statistically significant decreasing trend, at an annual rate of $0.02 \%$ representing $2.58 \%$ of the study period's average, (Table 2). Non-stability Coefficient reached $28.05 \%$, indicating stability in the relative importance of the value under study.

Studying Egypt's total balance of trade with Nile Basin countries reveals that it realized deficits over the period 1994-2003, ranging between a minimum of $0.12 \%$ of Egypt's total balance of trade in 2003 and a maximum of $1.92 \%$ in 2002 . However, it realized surpluses over the period 2004-2016, which contributed to reducing deficit in Egypt's total balance of trade by a minimum of $0.86 \%$ in 2014 and a maximum of $3.39 \%$ in 2010 . Regression analysis results reveal that the computed relative importance followed a statistically significant decreasing trend, at annual rate of $0.18 \%$ representing $26.07 \%$ of the study period's average, (Table 2). Non-stability Coefficient reached $315.08 \%$, indicating fluctuations in the relative importance of the value under study.

It is therefore clear that rates of trade exchange between Egypt and Nile Basin countries are low, which can be explained by: insufficient marketing information on market needs of Nile Basin countries; insufficient means of transport thus high cost of transportation; political instability in African countries in general and Nile Basin countries in particular, a situation that led to reluctance of businessmen (exporters and importers) to conclude commercial transactions; in addition, some of the Nile Basin countries have received grants and aid from other countries that have greedy ambitions and in the same time are competitors to Egypt. Accordingly, it is important for Egypt to exert efforts to regain her status and leadership in Africa by increasing joint projects that link together common interests of the Nile Basin countries.

\section{Relative Importance of Indicators on Egypt's Agricultural Trade with Nile Basin Countries}

It is clear from Table (1) that the relative importance of the value of Egypt's agricultural trade with Nile Basin countries to the total value of Egypt's agricultural trade has been fluctuating over the study period (1994-2016), recording a minimum of $1.86 \%$ in 2006 and a maximum of $21.19 \%$ in 2016, and a period's average of $5.99 \%$. Regression analysis results reveal that the computed relative importance followed a statistically significant increasing trend at an annual rate of $0.1 \%$ and an annual growth rate of $1.72 \%$. Non-stability coefficient reached $118.48 \%$, indicating fluctuations in the value under study.

Studying the relative importance of the value of Egypt's agricultural exports to Nile Basin countries over the study period (1994-2016) reveal that it has been 
Table (1): Importance of Egypt's Total and Agricultural Trade with Nile Basin Countries Relative to Egypt's Total and Agricultural Trade with World

Countries over the Period (1994-2016)

\begin{tabular}{|c|c|c|c|c|c|c|c|c|}
\hline Year & $\begin{array}{c}\text { Value of } \\
\text { total } \\
\text { trade } \\
\text { with Nile } \\
\text { Basin } \\
\text { countries } \\
\text { to total } \\
\text { trade } \\
\text { value }\end{array}$ & $\begin{array}{l}\text { Value of } \\
\text { total } \\
\text { exports } \\
\text { to Nile } \\
\text { Basin } \\
\text { countries } \\
\text { to total } \\
\text { exports } \\
\text { value }\end{array}$ & $\begin{array}{c}\text { Value of } \\
\text { total } \\
\text { imports } \\
\text { from } \\
\text { Nile } \\
\text { Basin } \\
\text { countries } \\
\text { to total } \\
\text { imports } \\
\text { value }\end{array}$ & $\begin{array}{c}\text { Balance } \\
\text { of trade } \\
\text { with Nile } \\
\text { Basin } \\
\text { countries } \\
\text { to total } \\
\text { balance } \\
\text { of trade }\end{array}$ & $\begin{array}{c}\text { Value of } \\
\text { agricultural } \\
\text { trade with } \\
\text { Nile Basin } \\
\text { countries to } \\
\text { total } \\
\text { agricultural } \\
\text { trade }\end{array}$ & $\begin{array}{c}\text { Value of } \\
\text { agricultural } \\
\text { exports to } \\
\text { Nile Basin } \\
\text { countries to } \\
\text { total } \\
\text { agricultural } \\
\text { exports } \\
\text { value }\end{array}$ & $\begin{array}{c}\text { Value of } \\
\text { agricultural } \\
\text { imports } \\
\text { from Nile } \\
\text { Basin } \\
\text { countries to } \\
\text { total } \\
\text { agricultural } \\
\text { imports } \\
\text { value }\end{array}$ & $\begin{array}{c}\text { Balance of } \\
\text { agricultural } \\
\text { trade with } \\
\text { Nile basin } \\
\text { countries to } \\
\text { total } \\
\text { balance of } \\
\text { agricultural } \\
\text { trade }\end{array}$ \\
\hline 1994 & 0.74 & 0.98 & 0.65 & 0.47 & 2.92 & 0.98 & 3.55 & 4.80 \\
\hline 1995 & 0.96 & 0.89 & 0.98 & 1.02 & 3.90 & 1.32 & 4.56 & 5.66 \\
\hline 1996 & 0.85 & 0.75 & 0.88 & 0.92 & 3.01 & 1.68 & 3.26 & 3.62 \\
\hline 1997 & 0.88 & 0.85 & 0.89 & 0.91 & 4.18 & 1.87 & 4.72 & 5.60 \\
\hline 1998 & 0.66 & 0.86 & 0.63 & 0.57 & 3.51 & 2.25 & 3.89 & 4.58 \\
\hline 1999 & 0.86 & 0.97 & 0.83 & 0.80 & 3.92 & 1.91 & 4.49 & 5.49 \\
\hline 2000 & 1.09 & 0.87 & 1.17 & 1.32 & 4.50 & 2.34 & 5.06 & 6.01 \\
\hline 2001 & 1.37 & 1.51 & 1.33 & 1.25 & 5.18 & 4.17 & 5.46 & 5.95 \\
\hline 2002 & 1.56 & 1.26 & 1.67 & 1.92 & 5.97 & 2.15 & 7.16 & 9.43 \\
\hline 2003 & 1.37 & 1.86 & 1.10 & 0.12 & 4.24 & 3.41 & 4.63 & 5.68 \\
\hline 2004 & 1.13 & 1.89 & 0.68 & -1.11 & 2.03 & 3.70 & 0.94 & -4.11 \\
\hline 2005 & 1.19 & 2.52 & 0.48 & -1.90 & 1.87 & 4.60 & 0.83 & -1.49 \\
\hline 2006 & 1.03 & 1.93 & 0.44 & -2.55 & 1.86 & 5.62 & 0.45 & -2.67 \\
\hline 2007 & 0.86 & 1.67 & 0.38 & -1.53 & 1.93 & 6.06 & 0.57 & -2.12 \\
\hline 2008 & 1.35 & 3.04 & 0.51 & -1.98 & 5.42 & 6.19 & 5.09 & 4.24 \\
\hline 2009 & 1.61 & 3.46 & 0.60 & -2.73 & 6.46 & 7.72 & 5.61 & 1.22 \\
\hline 2010 & 1.76 & 4.18 & 0.51 & -3.39 & 7.20 & 12.69 & 4.15 & -6.55 \\
\hline 2011 & 1.54 & 3.27 & 0.66 & -2.02 & 6.94 & 11.96 & 5.09 & 1.07 \\
\hline 2012 & 1.51 & 3.52 & 0.68 & -1.30 & 6.21 & 10.39 & 4.94 & 2.55 \\
\hline 2013 & 1.59 & 3.76 & 0.65 & -1.73 & 10.77 & 14.09 & 8.91 & 2.36 \\
\hline 2014 & 1.51 & 3.51 & 0.77 & -0.86 & 11.96 & 10.05 & 13.32 & 21.32 \\
\hline 2015 & 1.50 & 5.03 & 0.48 & -1.35 & 12.65 & 15.48 & 10.69 & -0.26 \\
\hline 2016 & 1.82 & 4.99 & 0.65 & -1.91 & 21.19 & 27.52 & 16.77 & -7.94 \\
\hline Average & 1.25 & 2.33 & 0.77 & -0.66 & 5.99 & 6.88 & 5.40 & 2.80 \\
\hline
\end{tabular}

Source : Calculated from table (1) in the annex.

Table (2): Simple Regression Equations

\begin{tabular}{|c|c|c|c|c|c|c|c|}
\hline Item & Equation & $\mathbf{T}$ & $\mathbf{R}^{2}$ & Sig. & Average & $\begin{array}{l}\text { Growth } \\
\text { Rate\% }\end{array}$ & $\begin{array}{c}\text { Non- } \\
\text { stability } \\
\text { Coefficient }\end{array}$ \\
\hline $\begin{array}{l}\text { Egypt's total value of trade with } \\
\text { Nile basin countries relative to } \\
\text { Egypt's total trade value }\end{array}$ & $\hat{\mathbf{Y}}_{\mathrm{i}}=0.76+0.04 x_{i}$ & 6.18 & 0.65 & $* *$ & 1.25 & 3.27 & 15.85 \\
\hline $\begin{array}{l}\text { Egypt's total value of exports to } \\
\text { Nile basin countries relative to } \\
\text { Egypt's total exports value }\end{array}$ & $\hat{\mathbf{Y}}_{\mathrm{i}}=0.01+0.19 x_{i}$ & 12.37 & 0.88 & $* *$ & 2.33 & 8.30 & 37.03 \\
\hline $\begin{array}{l}\text { Egypt's total value of imports from } \\
\text { Nile basin countries relative to } \\
\text { Egypt's total imports value }\end{array}$ & $\hat{\mathbf{Y}}_{\mathrm{i}}=1.0-0.02 x_{i}$ & -2.17 & 0.18 & * & 0.77 & -2.58 & 28.05 \\
\hline $\begin{array}{l}\text { Egypt's total balance of trade with } \\
\text { Nile basin countries to Egypt's } \\
\text { total trade balance }\end{array}$ & $\hat{\mathbf{Y}}_{\mathrm{i}}=1.4-0.18 x_{i}$ & -5.19 & 0.56 & $* *$ & $(0.66)$ & 26.07 & 315.08 \\
\hline $\begin{array}{l}\text { Egypt's value of agricultural trade } \\
\text { with Nile basin countries to } \\
\text { Egypt's agricultural trade }\end{array}$ & $\hat{\mathrm{Y}}_{\mathrm{i}}=1.41+0.1 \mathrm{x}_{\mathrm{i}}$ & 4.51 & 0.49 & $* *$ & 5.99 & 1.72 & 118.48 \\
\hline $\begin{array}{l}\text { Egypt's agricultural exports value } \\
\text { with Nile basin countries to the } \\
\text { Egypt's agricultural exports value }\end{array}$ & $\hat{\mathbf{Y}}_{\mathrm{i}}=-2.72+0.8 \mathrm{x}_{\mathrm{i}}$ & 7.65 & 0.74 & $* *$ & 6.88 & 11.63 & 77.0 \\
\hline $\begin{array}{l}\text { Egypt's agricultural imports value } \\
\text { with Nile basin countries to the } \\
\text { Egypt's agricultural imports value }\end{array}$ & $\hat{\mathbf{Y}}_{\mathrm{i}}=1.57+0.32 \mathrm{x}_{\mathrm{i}}$ & 3.03 & 0.30 & $* *$ & 5.40 & 5.91 & 50.02 \\
\hline $\begin{array}{l}\text { Egypt's agricultural balance with } \\
\text { Nile basin countries to the Egypt's } \\
\text { agricultural balance }\end{array}$ & $\hat{\mathbf{Y}}_{\mathrm{i}}=5.39-0.22 \mathrm{x}_{\mathrm{i}}$ & -1.15 & 0.06 & - & 2.80 & -7.69 & 266.87 \\
\hline
\end{tabular}

** at 0.01 level of significance,

* at 0.05 level of significance

Source: table (1). 
fluctuating, recording a minimum of $0.98 \%$ in 1994 , a maximum of $27.52 \%$ in 2016 , and a period's average of $6.88 \%$, (Table 1). Regression analysis results reveal that the computed relative importance followed a statistically significant increasing trend at an annual rate of $0.8 \%$ representing $11.66 \%$ of the period's average. Non-stability coefficient reached $77 \%$, indicating fluctuations in the value under study.

Studying the relative importance of the value of Egypt's agricultural imports from Nile Basin countries to the total value of Egypt's agricultural imports from world countries reveals that it has been fluctuating over the study period, ranging between a minimum of $0.45 \%$ in 2006 and a maximum of $16.77 \%$ in 2016 , recording an average of $5.4 \%$ (Table 1). Simple regression analysis reveals that the computed relative importance followed a statistically significant increasing trend at an annual rate of $0.32 \%$ representing $5.91 \%$ of the period's average (Table 2). Non-stability coefficient reached $55.02 \%$, indicating fluctuations in the relative importance of the value under study.

As for the relative importance of Egypt's balance of agricultural trade with Nile Basin countries, it has been fluctuating between surplus and deficit over the study period 1994-2016, recording a minimum deficit of $1.07 \%$ in 2011 and a maximum deficit of $21.32 \%$ in 2014 of the total value of Egypt's balance of agricultural trade with world countries. However, it realized a surplus that contributed to reducing deficit by a minimum of $0.26 \%$ in 2015 and a maximum of $7.94 \%$ in 2016 , but the achieved results did not prove statistically significant (Table 2).

It is therefore clear that the volume of agricultural trade with Nile basin countries is weak, which can be explained by the fact that most of the Nile Basin countries are members of other economic blocks competing Egypt, and that they are receiving better privileges from trade exchange with such blocks compared to trade exchange with Egypt. In addition, commodities and products imported from Nile Basin countries are primary and limited in number.

\section{Geographic Distribution of Trade with Nile Basin Countries Geographic Distribution of Total Trade with Nile Basin Countries}

Table (3) presents the relative importance of the geographic distribution of Egypt's total trade with Nile Basin countries over the period 1994-2016. It can be noted that Sudan, Kenya and Ethiopia are major trade partners with Egypt by absorbing $44.2 \%, 35.7 \%$ and $7.1 \%$ of Egypt's total trade with Nile Basin countries, respectively. Concentration Indicator (Gini Hirschman) reached 57.6, indicating that Egypt's total trade with Nile Basin countries is concentrated in a limited number of countries.

As for the geographic distribution of Egypt's exports to Nile Basin countries, results reveal that the same previously mentioned countries, i.e., Sudan, Kenya and Ethiopia absorb 55.8\%, 21.9\% and 6.8\% of Egypt's total exports to Nile Basin countries, respectively. Gini Hirschman indicator reached 60.72, indicating that

Egypt's exports to Nile Basin countries is concentrated in a limited number of countries. 
المجلة المصرية للاقتصاد الزراعي- المجلد الثامن و العشرون- العدد الثاني - بونيو 1 اـب

Table (3): Geographic Distribution of Egypt's Trade with Nile Basin Countries over the Period 1994-2016

\begin{tabular}{|c|c|c|c|c|c|c|}
\hline \multirow{2}{*}{ Country } & \multicolumn{3}{|c|}{ Total trade } & \multicolumn{3}{c|}{ Agricultural Trade } \\
\cline { 2 - 7 } & $\begin{array}{c}\text { Total } \\
\text { Trade }\end{array}$ & $\begin{array}{c}\text { Total } \\
\text { Exports }\end{array}$ & $\begin{array}{c}\text { Total } \\
\text { Imports }\end{array}$ & $\begin{array}{c}\text { Total } \\
\text { Trade }\end{array}$ & $\begin{array}{c}\text { Total } \\
\text { Exports }\end{array}$ & $\begin{array}{c}\text { Total } \\
\text { Imports }\end{array}$ \\
\hline Sudan & 44.20 & 55.77 & 20.60 & 27.57 & 51.70 & 8.76 \\
\hline Ethiopia & 7.09 & 6.76 & 7.76 & 5.49 & 4.21 & 6.50 \\
\hline Uganda & 2.92 & 3.61 & 1.50 & 1.92 & 2.98 & 1.08 \\
\hline Congo & 2.41 & 1.84 & 3.57 & 1.15 & 2.51 & 0.10 \\
\hline Kenya & 35.70 & 21.93 & 63.80 & 55.89 & 22.70 & 81.77 \\
\hline Tanzania & 2.61 & 3.10 & 1.63 & 1.66 & 3.08 & 0.55 \\
\hline Ruanda & 1.10 & 1.47 & 0.34 & 1.01 & 2.07 & 0.19 \\
\hline Burundi & 0.67 & 0.95 & 0.11 & 0.83 & 1.74 & 0.12 \\
\hline Eritrea & 3.30 & 4.58 & 0.69 & 4.48 & 9.02 & 0.93 \\
\hline Total & 100.00 & 100.00 & 100.00 & 100.00 & 100.00 & 100.00 \\
\hline $\begin{array}{c}\text { Gini Hirschman } \\
\text { Coefficient }\end{array}$ & 57.55 & 60.72 & 67.63 & 62.80 & 57.61 & 82.51 \\
\hline Souryyyyyyyyy
\end{tabular}

Source: Table (2) in statistical annex.

Turning to the geographic distribution of Egypt's total imports from Nile Basin countries, results reveal that Kenya, Sudan and Ethiopia are the major three countries from which Egypt receives imports, with shares amounting to $63.8 \%, 20.6 \%$ and $7.8 \%$ of Egypt's total imports from Nile Basin countries, respectively. Gini Hirschman indicator reached 67.63, indicating that Egypt's imports from Nile Basin countries is concentrated in a limited number of countries.

\section{Geographic Distribution of Agricultural Trade with Nile Basin Countries}

Studying the geographic distribution of Egypt's agricultural trade with Nile Basin countries reveals that Sudan, Kenya and Ethiopia come on top of the countries with which Egypt exchange agricultural trade by absorbing 55.9\%, 27.6\% and 5.5\% of Egypt's total agricultural trade with Nile Basin countries, respectively. Gini Hirschman indicator reached 62.8, indicating that Egypt's trade with Nile Basin countries is concentrated in a limited number of countries.

As regards the geographic distribution of Egypt's agricultural exports to Nile Basin countries, results reveal that Sudan, Kenya and Eretria absorb 51.7\%, 22.7\% and $9.02 \%$ of Egypt's agricultural exports to Nile Basin countries, respectively. Gini Hirschman indicator reached 57.6, indicating that Egypt's agricultural exports to Nile Basin countries is concentrated in a limited number of countries.

Turning to the geographic distribution of Egypt's agricultural imports from Nile Basin countries, results reveal that Kenya, Sudan and Ethiopia are the major three countries from which Egypt imports agricultural products, with shares amounting to $81.8 \%, 8.8 \%$ and $6.5 \%$ of Egypt's total agricultural imports from Nile Basin countries, respectively. Gini Hirschman indicator reached 82.5, indicating that Egypt's agricultural imports from Nile Basin countries is concentrated in a limited number of countries.

Such results indicate that Egypt's trade with Nile Basin countries is concentrated in a limited number of countries, which subjects Egypt to the risks associated with relying on certain markets including the occurrence of changes in local, regional and international variables. On the other hand, there exist opportunities for diversifying Egyptian agricultural trade with other Nile Basin 
countries as promising markets for both parties, particularly those which trade exchange with Egypt is still weak.

\section{Concentration of Egyptian Agricultural Commodities' Exports to Nile Basin Countries}

Table (4) presents a list of major agricultural commodities exported to Nile Basin countries over the period 2008-2016. It can be noted that sugar and sugar confectionary comes on top of the exported commodities by recording an value of US\$ 142.2 million representing $49.13 \%$ of the period's average value of major agricultural commodities exported to Nile Basin countries. Fruit and edible fruits followed by recording a value of US\$ 21.4 million representing 7.4\%. Animal and vegetable greases, fats, oils and waxes ranks third by recording a value of US\$20 million representing $6.9 \%$. Milling products, malt and starches ranks fourth recording a value of US\$ 17.1 million representing 5.9\%. Preparations of cereals, flour, starch, Gum and Varnishes and Vegetable Extracts, Miscellaneous Food Preparations, and Preparations of vegetables, fruit, nuts or other parts of plants followed by recording a values of US\$ $16.4,13.8,13.2$ and 12.8 million representing $5.7 \%, 4.8 \%, 4.5 \%$ and $4.4 \%$, respectively. Other commodities and/or products ranks last by recording a total value of US\$32.6 representing $11.3 \%$ of the period's average value of major agricultural commodities exported to Nile Basin countries.

Table (4), which presents a geographic distribution of Egyptian agricultural exports to Nile Basin countries over the period 2008-2016, reveals the following:

\section{Sugar and Sugar Confectionery ${ }^{(*)}$}

Sudan, Kenya, Tanzania and Uganda come on top of the countries to which Egypt exports sugar and sugar confectionery, with values amounting to US\$79.06, $43.8,7.56$ and 7.25 million representing $55.6 \%, 30.8 \%, 5.3 \%$ and $5.1 \%$ of the period's average value of exports from this category to Nile Basin countries, respectively. Gini Hirschman indicator reached 64.01, indicating that Egyptian exports of sugar and sugar confectionery is concentrated in a limited number of Nile Basin countries.

\section{Fruits and Edible Fruits}

Sudan comes on top of the countries to which Egypt exports fruits and edible fruits, with exports value amounting to US\$ 18.6 million representing $87.1 \%$ of the period's average value of exports from this category to Nile Basin countries. Kenya followed with exports value amounting to US\$ 2.45 million representing $11.47 \%$ of the period's average value of exports from this category to Nile Basin countries. Gini Hirschman indicator reached 87.85, indicating that Egypt's exports of fruits and edible fruits are concentrated in a limited number of Nile Basin countries.

\section{Plant and Animal Greases, Fats, Oils and Waxes ${ }^{(\Delta)}$}

As shown in Table 4, Ethiopia, Eritrea and Sudan come on top of the countries to which Egypt exports plant and animal greases, fats, oils and waxes, with export values amounting to US\$ 6.91, 5.85 and 5.43 million representing $34.56 \%, 29.26 \%$ and $27.17 \%$ of the period's average value of exports from this category to Nile Basin 
countries, respectively. Gini Hirschman indicator reached 53.18, indicating that Egypt's exports of plant and animal greases, fats, oils and waxes is concentrated in a limited number of Nile Basin countries.

\section{Grinder Products and Grain Starch}

Eritrea and Burundi come on top of the countries to which Egypt exports grinder products and grain starch, with export values amounting to US\$ 12.02 and 2.25 million representing $70.11 \%$ and $13.11 \%$ of the period's average value of exports from this category to Nile Basin countries, respectively. Gini Hirschman indicator reached 71.94, indicating that Egypt's exports of grinder products and grain starch is concentrated in a limited number of Nile Basin countries.

\section{Grain, Flour and Starch Preparations}

Eritrea Kenya and Sudan come on top of the countries to which Egypt exports grain, flour and starch preparations, with export values amounting to US\$ 7.82, 6.24 and 1.52 million representing $47.77 \%, 38.12 \%$ and $9.29 \%$ of the period's average value of exports from this category to Nile Basin countries, respectively. Gini Hirschman indicator reached 61.86, indicating that Egypt's exports of grain, flour and starch preparations is concentrated in a limited number of Nile Basin countries.

\section{Gum and Varnishes and Vegetable Extracts}

Congo, Sudan, Rwanda, Burundi and Ethiopia come on top of the countries to which Egypt exports gum and varnishes and vegetable extracts, with export values amounting to US\$ 5.44, 2.46, 2.35, 2.18 and 1.41 million representing $39.32 \%$, $17.78 \%, 16.98 \%, 15.75 \%$ and $10.17 \%$ of the period's average value of exports from this category to Nile Basin countries, respectively. Gini Hirschman indicator reached 50.02, indicating that Egypt's exports of gum and varnishes and vegetable extracts is concentrated in a limited number of Nile Basin countries.

\section{Miscellaneous Food Preparations}

Sudan, Ethiopia and Kenya come on top of the countries to which Egypt exports Miscellaneous Food Preparations, with export values amounting to US\$ 8.97, 1.93 and 1.45 million representing $68.18 \%, 14.64 \%$ and $11.01 \%$ of the period's average value of exports from this category to Nile Basin countries, respectively. Gini Hirschman indicator reached 70.67, indicating that Egypt's exports of miscellaneous food preparations is concentrated in a limited number of Nile Basin countries.

\section{Vegetables and Fruits Preparations and Parts}

Sudan, Kenya and Congo come on top of the countries to which Egypt exports vegetables and fruits preparations and parts, with export values amounting to US\$ $7.17,2.55$ and 1.04 million representing $55.81 \%, 19.84 \%$ and $8.14 \%$ of the period's average value of exports from this category to Nile Basin countries, respectively. Gini Hirschman indicator reached 60.43, indicating that Egypt's exports of vegetables and fruits preparations and parts are concentrated in a limited number of Nile Basin countries. 
Table (4): Concentration of Egypt's Exports of Agricultural Commodities to NB countries over the period 2008-2016

\begin{tabular}{|c|c|c|c|c|c|c|c|c|}
\hline \multirow[t]{2}{*}{ Country } & \multicolumn{2}{|c|}{$\begin{array}{c}\text { Sugar and } \\
\text { Sugar } \\
\text { Confectionery }\end{array}$} & \multicolumn{2}{|c|}{$\begin{array}{l}\text { Fruits and } \\
\text { Edible Fruits }\end{array}$} & \multicolumn{2}{|c|}{$\begin{array}{l}\text { Plant and } \\
\text { animal } \\
\text { greases, fats, } \\
\text { oils and waxes } \\
\end{array}$} & \multicolumn{2}{|c|}{$\begin{array}{l}\text { Milling } \\
\text { products, malt } \\
\text { and starches }\end{array}$} \\
\hline & Value & $\%$ & Value & $\%$ & Value & $\%$ & Value & $\%$ \\
\hline Sudan & 79.06 & 55.59 & 18.61 & 87.09 & 5.43 & 27.17 & 0.86 & 5.00 \\
\hline Ethiopia & 0.32 & 0.22 & -- & 0.00 & 6.91 & 34.56 & 0.68 & 3.95 \\
\hline Uganda & 7.25 & 5.10 & 0.25 & 1.16 & 0.19 & 0.96 & -- & 0.00 \\
\hline Congo & 0.99 & 0.70 & 0.06 & 0.28 & -- & 0.00 & -- & 0.00 \\
\hline Kenya & 43.82 & 30.81 & 2.45 & 11.47 & 1.22 & 6.11 & 0.002 & 0.01 \\
\hline Tanzania & 7.56 & 5.31 & -- & 0.00 & 0.10 & 0.52 & 0.18 & 1.03 \\
\hline Ruanda & 2.06 & 1.45 & -- & 0.00 & 0.16 & 0.82 & 1.16 & 6.79 \\
\hline Burundi & 0.08 & 0.05 & -- & 0.00 & 0.12 & 0.60 & 2.25 & 13.11 \\
\hline Eritrea & 1.09 & 0.77 & -- & 0.00 & 5.85 & 29.26 & 12.02 & 70.11 \\
\hline Total & 142.23 & 100.00 & 21.37 & 100.00 & 19.99 & 100.00 & 17.14 & 100.00 \\
\hline $\begin{array}{l}\text { Egyptian exports of } \\
\text { agricultural } \\
\text { commodities to Nile } \\
\text { basin countries (\%) }\end{array}$ & \multicolumn{2}{|c|}{49.13} & \multicolumn{2}{|c|}{7.4} & \multicolumn{2}{|c|}{6.9} & \multicolumn{2}{|c|}{5.9} \\
\hline $\begin{array}{l}\text { Gini Hirschman } \\
\text { Coefficient }\end{array}$ & \multicolumn{2}{|c|}{64.01} & \multicolumn{2}{|c|}{87.85} & \multicolumn{2}{|c|}{53.18} & \multicolumn{2}{|c|}{71.94} \\
\hline Country & \multicolumn{2}{|c|}{$\begin{array}{l}\text { Grain, flour } \\
\text { and starch } \\
\text { preparations }\end{array}$} & \multicolumn{2}{|c|}{$\begin{array}{c}\text { Gum and } \\
\text { varnishes and } \\
\text { vegetable } \\
\text { extracts }\end{array}$} & \multicolumn{2}{|c|}{$\begin{array}{c}\begin{array}{c}\text { Miscellaneous } \\
\text { food } \\
\text { preparations }\end{array} \\
\text { pred }\end{array}$} & \multicolumn{2}{|c|}{$\begin{array}{c}\text { Vegetables and } \\
\text { fruits } \\
\text { preparations and } \\
\text { parts }\end{array}$} \\
\hline & Value & $\%$ & Value & $\%$ & Value & $\%$ & Value & $\%$ \\
\hline Sudan & 1.52 & 9.29 & 2.46 & 17.78 & 8.97 & 68.18 & 7.17 & 55.81 \\
\hline Ethiopia & 0.10 & 0.63 & 1.41 & 10.17 & 1.93 & 14.64 & 0.39 & 3.04 \\
\hline Uganda & 0.28 & 1.71 & -- & 0.00 & 0.11 & 0.86 & 0.64 & 4.97 \\
\hline Congo & 0.17 & 1.04 & 5.44 & 39.32 & 0.21 & 1.56 & 1.04 & 8.14 \\
\hline Kenya & 6.24 & 38.12 & -- & 0.00 & 1.45 & 11.01 & 2.55 & 19.84 \\
\hline Tanzania & 0.06 & 0.37 & -- & 0.00 & 0.32 & 2.41 & 0.21 & 1.64 \\
\hline Ruanda & 0.11 & 0.69 & 2.35 & 16.98 & 0.05 & 0.41 & -- & 0.00 \\
\hline Burundi & 0.06 & 0.39 & 2.18 & 15.75 & 0.03 & 0.22 & 0.03 & 0.22 \\
\hline Eritrea & 7.82 & 47.77 & -- & 0.00 & 0.09 & 0.70 & 0.81 & 6.33 \\
\hline Total & 16.37 & 100.00 & 13.84 & 100.00 & 13.16 & 100.00 & 12.84 & 100.00 \\
\hline $\begin{array}{l}\text { Egyptian exports of } \\
\text { agricultural } \\
\text { commodities to Nile } \\
\text { basin countries }(\%)\end{array}$ & \multicolumn{2}{|c|}{5.7} & \multicolumn{2}{|c|}{4.8} & \multicolumn{2}{|c|}{4.5} & \multicolumn{2}{|c|}{4.4} \\
\hline $\begin{array}{c}\text { Gini Hirschman } \\
\text { Coefficient }\end{array}$ & \multicolumn{2}{|c|}{61.86} & \multicolumn{2}{|c|}{50.02} & \multicolumn{2}{|c|}{70.67} & \multicolumn{2}{|c|}{60.43} \\
\hline
\end{tabular}

Source: Computed based on data collected from the Central Agency for Public Mobilization and Statistics (CAPMAS).

\section{Commodity Concentration of Egyptian Imports from Nile Basin Countries}

Data in Table (5) reveals that major commodities which Egypt imports from Nile Basin countries is concentrated in 5 categories representing $97.28 \%$ of the period's average value of agricultural commodities imported from Nile Basin Countries. Coffee and tea come on top of the imported commodities with an average value of US\$ 255.3 million representing $73.6 \%$ of the period's average value of agricultural commodities imported from Nile Basin Countries; followed by: live animals, with imports value amounting to US\$ 27.34 million representing 7.88\%; oilseeds, with imports value amounting to US\$ 26.01 million representing $7.5 \%$; tobacco, with imports value amounting to US\$ 15.89 million representing $4.58 \%$; 
finally, imports of cotton recorded a value of US\$ 12.9 million representing 3.72\%. The rest of commodities and/or products recorded a value of US\$ 9.42 million representing $2.72 \%$ of the period's average value of agricultural commodities imported from Nile Basin Countries.

Table (5) also presents the geographic distribution of major agricultural commodities Egypt imports from Nile Basin countries over the period 2008-2016:

\section{Coffee and Tea}

It can be noted from the table that Kenya comes on top of the countries from which Egypt imports coffee and tea, with imports value amounting to US\$ 247.71 million representing $97.04 \%$ of the period's average value of Egyptian imports of coffee and tea. Gini Hirschman indicator reached 97.05, indicating that coffee and tea imports are concentrated in a limited number of Nile Basin countries.

\section{Live Animals}

Ethiopia, Sudan and Kenya come on top of the countries from which Egypt imports live animals, with imports values amounting to US\$21.71, 5.27 and 0.36 million representing $79.41 \%, 19.26 \%$ and $1.33 \%$ of the period's average value of imports from live animals, respectively. Gini Hirschman indicator reached 81.72, indicating that imports of live animals are concentrated in a limited number of Nile Basin countries.

\section{Oilseeds}

Sudan and Ethiopia come on top of the countries from which Egypt imports oilseeds, with imports values amounting to US\$ 21.17 and 3.85 million representing $81.41 \%$ and $14.8 \%$ of the period's average value of imports from oilseeds, respectively. Gini Hirschman indicator reached 82.81, indicating that oilseeds imports are concentrated in a limited number of Nile Basin countries.

Table (5): Concentration of Egyptian imports of agricultural commodities from NB Countries over the Period 2008 -2016

\begin{tabular}{|c|c|c|c|c|c|c|c|c|c|c|}
\hline \multirow{2}{*}{ Country } & \multirow{2}{*}{\multicolumn{2}{|c|}{ Coffee \& Tea }} & \multicolumn{2}{|c|}{ Live animals } & \multicolumn{2}{|c|}{ Oilseeds } & \multicolumn{2}{|c|}{ Tobacco } & \multicolumn{2}{|c|}{ cotton } \\
\hline & & & Value & $\%$ & Value & $0 \%$ & Value & $\%$ & Value & $\%$ \\
\hline Sudan & -- & 0.0 & 5.27 & 19.26 & 21.17 & 81.41 & -- & 0.0 & 12.64 & 98.00 \\
\hline Ethiopia & 0.69 & 0.27 & 21.71 & 79.41 & 3.85 & 14.80 & -- & 0.0 & -- & 0.0 \\
\hline Uganda & 2.43 & 0.95 & -- & 0.0 & 0.07 & 0.28 & 0.36 & 2.30 & -- & 0.0 \\
\hline Congo & & 0.0 & & 0.0 & & 0.0 & & 0.0 & & 0.0 \\
\hline Kenya & 247.71 & 97.04 & 0.36 & 1.33 & 0.87 & 3.34 & 15.43 & 97.10 & 0.11 & 0.85 \\
\hline Tanzania & 0.67 & 0.26 & -- & 0.0 & 0.02 & 0.08 & 0.09 & 0.54 & -- & 0.0 \\
\hline Ruanda & 0.73 & 0.29 & -- & 0.0 & 0.02 & 0.06 & 0.01 & 0.07 & & 0.0 \\
\hline Burundi & 0.24 & 0.09 & -- & 0.0 & 0.01 & 0.02 & -- & 0.0 & 0.04 & 0.29 \\
\hline Eritrea & 2.8 & 1.10 & -- & 0.0 & -- & 0.0 & & 0.0 & 0.11 & 0.86 \\
\hline Total & 255.26 & 100.00 & 27.34 & 100.00 & 26.01 & 100.00 & 15.89 & 100.00 & 12.90 & 100.00 \\
\hline $\begin{array}{l}\text { \% Egyptian } \\
\text { imports of agric. } \\
\text { commodities to } \\
\text { the Nile Basin } \\
\text { countries }\end{array}$ & & & & & & & & 58 & & 72 \\
\hline $\begin{array}{c}\text { Gini Hirschman } \\
\text { Indicator }\end{array}$ & & & & & & & & 13 & & 01 \\
\hline
\end{tabular}

Source: Computed based on data collected from the Central Agency for Public Mobilization and Statistics (CAPMAS). 


\section{Tobacco}

Kenya comes on top of the countries from which Egypt imports tobacco, with imports values amounting to US\$ 15.43 million representing $97.1 \%$ of the period's average value of tobacco imports. Gini Hirschman indicator reached 97.13, indicating that tobacco imports are concentrated in a limited number of Nile Basin countries.

\section{Cotton (ם)}

Sudan comes on top of the countries from which Egypt imports cotton, with imports values amounting to US\$ 12.64 million representing $98 \%$ of the period's average value of cotton imports. Gini Hirschman indicator reached 98.01, indicating that cotton imports are concentrated in a limited number of Nile Basin countries.

It can therefore be noted that Sudan and Kenya are the two main countries to which Egypt exports (sugar and sugar confectionary, fruits and edible fruits, miscellaneous food preparations, vegetables and fruits preparations and parts); whereas Eritrea is the main country to which Egypt exports (plant and animal greases, fats, oils and waxes, milling products, malt and starches Grain, flour and starch preparations). As for imports from Nile Basin countries, Kenya is the main country from which Egypt imports tea, coffee and tobacco; Sudan and Ethiopia are the two main countries from which Egypt imports live animals and oilseeds; and finally, Sudan is the main country from which Egypt imports cotton.

Table (6): Indices of Exports Similarity ${ }^{(*)}$ between Egypt and NB countries during period 2008-2016

\begin{tabular}{|c|c|c|c|c|c|c|c|c|}
\hline Year & Sudan & Ethiopia & Uganda & $\begin{array}{c}\text { D.R.of } \\
\text { Congo }\end{array}$ & Kenya & Tanzania & Ruanda & Burundi \\
\hline $\mathbf{2 0 0 8}$ & 3.09 & 4.65 & 42.39 & 32.48 & 37.78 & 37.21 & 4.44 & 22.14 \\
\hline $\mathbf{2 0 0 9}$ & 0.70 & 4.60 & 38.37 & 14.12 & 27.36 & 21.92 & 4.65 & 27.05 \\
\hline $\mathbf{2 0 1 0}$ & 2.59 & 8.57 & 37.56 & 11.71 & 24.33 & 27.38 & 5.52 & 14.21 \\
\hline $\mathbf{2 0 1 1}$ & 5.36 & 5.90 & 39.92 & 13.16 & 27.90 & 24.51 & 12.54 & 4.20 \\
\hline $\mathbf{2 0 1 2}$ & 12.00 & 4.51 & 42.51 & 13.29 & 29.10 & 32.12 & 15.76 & 2.51 \\
\hline $\mathbf{2 0 1 3}$ & 5.64 & 5.87 & 35.43 & 12.92 & 30.09 & 24.95 & 24.11 & 12.19 \\
\hline $\mathbf{2 0 1 4}$ & 6.41 & 7.72 & 26.06 & 13.36 & 31.96 & 24.74 & 24.08 & 12.84 \\
\hline $\mathbf{2 0 1 5}$ & 4.97 & 4.60 & 30.53 & 14.59 & 33.54 & 33.98 & 27.63 & 11.74 \\
\hline $\mathbf{2 0 1 6}$ & 5.91 & 4.59 & 30.19 & 9.20 & 35.25 & 24.83 & 20.51 & 11.06 \\
\hline Average & $\mathbf{5 . 1 9}$ & $\mathbf{5 . 6 7}$ & $\mathbf{3 5 . 8 8}$ & $\mathbf{1 4 . 9 8}$ & $\mathbf{3 0 . 8 1}$ & $\mathbf{2 7 . 9 6}$ & $\mathbf{1 5 . 4 7}$ & $\mathbf{1 3 . 1 0}$ \\
\hline
\end{tabular}

(*) Commodities were:

Live animals 01, Dairy produce; birds' eggs: natural honev: edible products of animal origin. not elsewhere specified or included 04 . Edible vegetables and certain roots and tubers 07. Edible fruit and nuts: peel of citrus fruit or melons 08. Coffee, tea, maté and spices 09. Cereals 10. Products of the milling industrv: malt: starches: inulin: wheat gluten 11. Oil seeds and oleaginous fruits: miscellaneous grains. seeds and fruit: industrial or medicinal plants: straw fodder 12. Lac: gums. resins and other vegetable sabs and extracts 13. Animal or vegetable fats and oils and their cleavage products: prepared edible fats: animal or vegtable15. Sugars and sugar confectionerv 17. Preparations of cereals. flour. starch or milk: pastrv cooks' products 19. Preparations of vegetables, fruit, nuts or other parts of plants 20. Miscellaneous edible preparations 21, Tobacco and manufactured tobacco substitutes 24, cotton 52.

Source: https://www.trademap.org

\section{Export Similarity Index}

Export similarity index usually ranges between 1 and 100. The higher the value of this index the more exports between two countries or blocks are said to be similar. 
It can be noted from table $\mathbf{6}$ that export similarity index for agricultural commodities traded between Egypt and Nile Basin countries is low, where it reached $18.63 \%$, indicating that the structure of exports between the two parties is more integrated. The index also showed low values regarding exports between Egypt and each of Sudan, Ethiopia, Congo, Ruanda and Burundi,

indicating that the structure of exports between Egypt and each of the mentioned countries is more integrated, hence, scope of trade creation is not wide, rather, there are chances for increasing trade exchange between Egypt and the mentioned countries to benefit from the broad markets. On the other hand, the index showed high values regarding exports between Egypt and each of Uganda, Kenya and Tanzania, indicating that the structure of exports between Egypt and each of the mentioned countries is more competitive, thus scope for trade creation is wide.

\section{Trade Compatibility Index}

This part studies the degree of trade compatibility between Egypt and Nile Basin countries, focusing on those commodities with high relative importance in trade exchange between the two parties (listed in tables 7 and 8). Results reveal the following:

Index of trade compatibility between Egyptian exports and Nile Basin countries' imports of the agricultural commodities under study ranges between an average of 0.947 and 0.998 (table 7), indicating high trade compatibility between Egyptian exports and Nile Basin countries' imports of the agricultural commodities under study. It is clear from table (8) that index of trade compatibility between Egyptian exports and Nile Basin countries' imports of the agricultural commodities under study ranges between an average of 0.871 and 0.998, indicating high trade compatibility between Egyptian imports and Nile Basin countries' exports of the agricultural commodities under study.

Comparing trade compatibility indices in tables $(7,8)$ reveal higher compatibility between Egyptian exports of the first 8 commodities listed in

table (7) than Egyptian imports from the same commodities, listed in table (8), indicating that Egypt is considered a promising market for imports from Nile Basin countries rather than exports to them, which in turn indicates transformation of trade in agricultural commodities at the account of agricultural commodities and products Nile Basin countries import from other countries to a degree higher than substituting agricultural commodities and products from Nile Basin countries by those imported by Egypt from other countries.

In addition, comparing trade compatibility indices for the last five commodities listed in tables $(7,8)$ reveal higher compatibility of Egyptian imports of agricultural commodities listed in table (8), except for cotton, than Egyptian exports from the same commodities, listed in table (7), indicating that Nile Basin countries are considered promising markets for imports from Egypt rather than exports to them, which in turn indicates transformation of trade in agricultural commodities at the account of agricultural commodities and products Egypt imports from other countries to a degree higher than substituting agricultural commodities and products from Egypt by those imported by Nile Basin countries from other countries. 
Table (7): Trade Compatibility Index for Egyptian Exports of Agricultural Commodities and NB Countries' Imports of Agricultural Commodities over the Period 2008-2016

\begin{tabular}{|c|c|c|c|c|c|c|c|c|c|}
\hline Commodities & Sudan & Ethiopia & Uganda & $\begin{array}{c}\text { Dem. } \\
\text { Rep } \\
\text { of } \\
\text { Congo }\end{array}$ & Kenya & Tanzania & Rwanda & Burundi & Average \\
\hline $\begin{array}{l}\text { Sugar and sugar } \\
\text { confectionery }\end{array}$ & 0.987 & 0.970 & 0.989 & 0.982 & 0.982 & 0.978 & 0.975 & 0.972 & 0.979 \\
\hline $\begin{array}{c}\text { Fruits and edible } \\
\text { fruits }\end{array}$ & 0.982 & 0.982 & 0.982 & 0.984 & 0.994 & 0.938 & 0.981 & 0.985 & 0.979 \\
\hline $\begin{array}{l}\text { Plant and animal } \\
\text { greases, fats, oils } \\
\text { and waxes }\end{array}$ & 0.935 & 0.935 & 0.979 & 0.989 & 0.960 & 0.974 & 0.956 & 0.935 & 0.958 \\
\hline $\begin{array}{l}\text { Gum and varnishes } \\
\text { and vegetable } \\
\text { extracts }\end{array}$ & 0.966 & 0.998 & 0.999 & 0.978 & 0.9996 & 0.999 & 0.997 & 0.999 & 0.992 \\
\hline $\begin{array}{l}\text { Vegetables and } \\
\text { fruits preparations } \\
\text { and it's parts }\end{array}$ & 0.995 & 0.995 & 0.998 & 0.981 & 0.983 & 0.999 & 0.996 & 0.994 & 0.993 \\
\hline $\begin{array}{l}\text { Miscellaneous food } \\
\text { preparations }\end{array}$ & 0.991 & 0.991 & 0.995 & 0.999 & 0.996 & 0.993 & 0.996 & 0.992 & 0.994 \\
\hline $\begin{array}{l}\text { Grinder Products, } \\
\text { and grain starch }\end{array}$ & 0.998 & 0.998 & 0.985 & 0.988 & 0.9998 & 0.982 & 0.956 & 0.987 & 0.987 \\
\hline $\begin{array}{l}\text { Grain, flour and } \\
\text { starch } \\
\text { preparations }\end{array}$ & 0.993 & 0.994 & 0.9999 & 0.994 & 0.995 & 0.994 & 0.998 & 0.993 & 0.995 \\
\hline 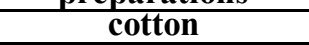 & 0.98 & 97 & 0.986 & 0.972 & 0.97 & 0.996 & 0.965 & 0.970 & 0.976 \\
\hline Live & & & & 97 & & & & 0.994 & 0.971 \\
\hline Coffee & & & & & & & & & 0.802 \\
\hline Toba & 0.98 & 0.981 & 0.9 & 0.919 & 0.9 & 0. & 0. & 0.999 & 0.970 \\
\hline Oilseeds & 0.846 & 0.923 & 0.964 & 0.976 & 0.949 & 0.994 & 0.952 & 0.947 & 0.944 \\
\hline
\end{tabular}

- Trade Map "Trade Statistics for International Business Development", www.trademap.org. Source: Computed based on data collected from the Central Agency for Public Mobilization and Statistics (CAPMAS).

Table (8): Trade Compatibility Index for Egyptian Imports of Agricultural
Commodities and NB Countries' Exports of Agricultural Commodities over the Period 2008-2016

\begin{tabular}{|c|c|c|c|c|c|c|c|c|c|}
\hline Commodities & Sudan & Ethiopia & Uganda & $\begin{array}{c}\text { Dem. } \\
\text { Rep } \\
\text { of } \\
\text { Congo } \\
\end{array}$ & Kenya & Tanzania & Rwanda & Burundi & Average \\
\hline $\begin{array}{c}\text { Sugar and sugar } \\
\text { confectionery }\end{array}$ & 0.987 & 0.970 & 0.989 & 0.982 & 0.982 & 0.978 & 0.975 & 0.972 & 0.979 \\
\hline Fruits and edible fruits & $\mathbf{0 . 9 8 2}$ & 0.982 & 0.982 & $\mathbf{0 . 9 8 4}$ & 0.994 & 0.938 & 0.981 & 0.985 & 0.979 \\
\hline $\begin{array}{l}\text { plant and animal greases, } \\
\text { fats, oils and waxes }\end{array}$ & 0.935 & 0.935 & 0.979 & 0.989 & 0.960 & 0.974 & 0.956 & 0.935 & 0.958 \\
\hline $\begin{array}{c}\text { Gum and varnishes and } \\
\text { vegetable extracts }\end{array}$ & 0.966 & 0.998 & 0.999 & 0.978 & 0.9996 & 0.999 & 0.997 & 0.999 & 0.992 \\
\hline $\begin{array}{l}\text { Vegetables and fruits } \\
\text { preparations and parts }\end{array}$ & 0.995 & 0.995 & 0.998 & 0.981 & 0.983 & 0.999 & 0.996 & 0.994 & 0.993 \\
\hline $\begin{array}{c}\text { Miscellaneous food } \\
\text { preparations }\end{array}$ & 0.991 & 0.991 & 0.995 & 0.999 & 0.996 & 0.993 & 0.996 & 0.992 & 0.994 \\
\hline $\begin{array}{c}\text { Grinder Products, and } \\
\text { grain starch }\end{array}$ & 0.998 & 0.998 & 0.985 & .988 & 0.9998 & 0.982 & 0.956 & 0.987 & 0.987 \\
\hline $\begin{array}{l}\text { Grain, flour and starch } \\
\text { preparations }\end{array}$ & 0.993 & 0.994 & 0.9999 & 0.994 & 0.995 & 0.994 & 0.998 & 0.993 & 0.995 \\
\hline & $\mathbf{0 . 9 8 8}$ & 0.971 & 0.986 & 0.972 & 0.965 & 0.996 & 0.965 & 0.970 & 0.976 \\
\hline Live & 4 & & & $\mathbf{0 . 9 9 7}$ & 0.995 & & & 0.994 & 0.971 \\
\hline Coft & & & & 0.900 & 7 & & & 592 & 0.802 \\
\hline Tobacco & 0.981 & & 0.978 & 0.919 & 0.987 & 0.936 & 0.982 & 0.999 & 0.970 \\
\hline Oilseeds & 0.846 & 0.923 & 0.964 & 0.976 & 0.949 & 0.994 & 0.952 & 0.947 & 0.944 \\
\hline
\end{tabular}

- Trade Map "Trade Statistics for International Business Development", www.trademap.org.

Source : Computed based on data collected from the Central Agency for Public Mobilization and Statistics (CAPMAS). 


\section{Compassing Competence}

Results presented in table (9) reveal that competence of Nile Basin countries' markets to absorb Egyptian exports ranges between a minimum of $57.5 \%$ in 2014 and a maximum of $71.14 \%$ in 2010 .

Table (9): Competence of the NB Countries' Markets to Absorb Egyptian Exports over the Period 2008-2016.

\begin{tabular}{|c|c|c|c|c|c|c|c|c|c|c|}
\hline \multirow[t]{3}{*}{ Year } & \multicolumn{2}{|c|}{$\begin{array}{c}\text { Egyptian exports } \\
\text { to NB countries }\end{array}$} & \multicolumn{2}{|c|}{$\begin{array}{l}\text { Egypt and NB } \\
\text { countries' Imports } \\
\text { from the world }\end{array}$} & \multicolumn{2}{|c|}{$\begin{array}{l}\text { Egypt and NB } \\
\text { countries' } \\
\text { Imports from the } \\
\text { world/ Egyptian } \\
\text { exports to NB } \\
\text { countries }\end{array}$} & \multicolumn{2}{|c|}{$\begin{array}{l}\text { (Egypt and NB } \\
\text { countries' } \\
\text { Imports from the } \\
\text { world/ "min" } \\
\text { (Egypt and NB } \\
\text { countries' } \\
\text { Imports from the } \\
\text { world/ Egyptian } \\
\text { exports to NB } \\
\text { countries)) }\end{array}$} & \multicolumn{2}{|c|}{$\begin{array}{l}\text { Compassing } \\
\text { Competence }\end{array}$} \\
\hline & Total & Agric. & Total & Agric. & Total & Agric. & Total & Agric. & Total & Agric. \\
\hline & $\begin{array}{l}\mathbf{E x} \\
\text { (1) }\end{array}$ & $\begin{array}{l}\mathbf{E x} \\
\text { (2) }\end{array}$ & $\begin{array}{l}\text { Im } \\
\text { (3) }\end{array}$ & $\begin{array}{l}\text { Im } \\
\text { (4) }\end{array}$ & $\begin{array}{l}\mathbf{I m} / \mathbf{E x} \\
(3) /(1)\end{array}$ & $\begin{array}{l}\operatorname{Im} / \mathbf{E x} \\
(4) /(2)\end{array}$ & \multicolumn{2}{|c|}{$\operatorname{Im} / \min (\operatorname{Im} / \mathbf{E x})$} & \multicolumn{2}{|c|}{$\operatorname{Ex} /(\operatorname{Im} / \min (\operatorname{Im} / \mathbf{E x}))$} \\
\hline 2008 & 798.03 & 129.4 & 114823.5 & 11429.1 & 143.9 & 88.3 & 1289.6 & 438.2 & 61.88 & 29.53 \\
\hline 2009 & 838.3 & 228.8 & 90039.5 & 11715.1 & 107.4 & 51.2 & 1011.2 & 449.2 & 82.90 & 50.95 \\
\hline 2010 & 1144.5 & 397.7 & 101910 & 10372.8 & 89.04 & 26.1 & 1144.5 & 397.7 & 100.00 & 100.00 \\
\hline 2011 & 1032.9 & 361.7 & 120539.6 & 16562.7 & 116.7 & 45.8 & 1353.8 & 635.0 & 76.30 & 56.95 \\
\hline 2012 & 1029.5 & 278.8 & 131236.2 & 17053.4 & 127.5 & 61.2 & 1473.9 & 653.9 & 69.85 & 42.64 \\
\hline 2013 & 1079.2 & 404.6 & 136961.6 & 19265 & 126.9 & 47.6 & 1538.2 & 738.7 & 70.16 & 54.77 \\
\hline 2014 & 965.6 & 296.8 & 149460.8 & 21457 & 154.8 & 72.3 & 1678.6 & 822.7 & $\mathbf{5 7 . 5 2}$ & 36.08 \\
\hline 2015 & 1073.5 & 441.5 & 156354 & 24325 & 145.7 & 55.1 & 1756.0 & 932.7 & 61.13 & 47.34 \\
\hline 2016 & 1104.6 & 736.5 & 162414 & 24589 & 147.04 & 33.4 & 1824.1 & 942.8 & 60.56 & 78.12 \\
\hline Average & 1007.3 & 364.0 & 129304.4 & 17418.8 & - & - & - & - & 71.14 & 55.15 \\
\hline
\end{tabular}

Source: Computed based on data collected from the Central Agency for Public Mobilization and Statistics (CAPMAS).

On the other hand, it can be noted that competence of Nile Basin countries' markets to absorb Egyptian exports of agricultural commodities ranges between a minimum of $29.5 \%$ in 2008 and a maximum of $100 \%$ in 2010 , recording an average of $55.15 \%$.

Based on the achieved results, it can be stated that competence of Nile Basin countries' markets to absorb exports of Egyptian commodities, either total or agricultural, has notably improved over the study period.

\section{Summary}

Recently, interest in enhancing trade relations between Egypt and African countries has been renewed, besides upgrading economic cooperation mechanisms between both parties. Such orientation has been reflected in the Government of Egypt's tendency towards developing perceptions and coordinating efforts in this direction, especially in light of contemporary local, regional and global changes, which have necessitated the pursuit of closer trade between Egypt and countries of the African continent in general, and Nile Basin countries in particular, an issue of strategic importance to Egypt's national water security system that calls for dealing 
with these countries in the framework of a comprehensive strategic perception that depends on linking the common interests of the Nile Basin countries together, either in the form of bilateral or multilateral agreements, such as the Nile Basin Initiative, which was signed by the ten Nile Basin countries in February 1999. And despite the large number of countries that joined the Nile Basin Initiative and the numerous products and commodities these countries produce, whether raw, intermediate, or even final, reality shows that trade between Egypt and Nile Basin countries is still weak. The main objective this research aimed to achieve is to study evolution in total and agricultural trade between Egypt and Nile Basin Countries, geographic distribution and commodity concentration of traded goods, to measure the degree of similarity and compatibility between Egypt and Nile Basin countries' export structure, and to measure Nile Basin countries markets' competence to absorb Egyptian exports. Main findings indicate the following:

- Relative importance of the value of Egypt's total trade with Nile Basin countries over the period 1994-2016 has been increasing at an annual rate of 3.27\%.

- Relative importance of the value of Egypt's total exports to Nile Basin countries over the period 1994-2016 has been increasing at an annual rate of $8.3 \%$.

- Relative importance of the value of Egypt's agricultural trade with Nile Basin countries to the total value of Egypt's agricultural trade over the period 1994-2016 has been growing at an annual rate of $1.72 \%$.

- Relative importance of the value of Egypt's agricultural exports to Nile Basin countries over the study period 1994-2016 has been increasing trend at an annual rate of $11.63 \%$.

- Geographic distribution of Egypt's agricultural exports to Nile Basin countries revealed that Sudan, Kenya and Eretria absorb 51.7\%, 22.7\% and 9.02\% of Egypt's agricultural exports to Nile Basin countries, respectively. Gini Hirschman indicator reached 57.6, indicating that Egypt's agricultural exports to Nile Basin countries is concentrated in a limited number of countries.

- Geographic distribution of Egypt's agricultural imports from Nile Basin countries revealed that Kenya, Sudan and Ethiopia are the major three countries from which Egypt imports agricultural products, with shares amounting to $81.8 \%, 8.8 \%$ and $6.5 \%$ of Egypt's total agricultural imports from Nile Basin countries, respectively. Gini Hirschman indicator reached 82.5, indicating that Egypt's agricultural imports from Nile Basin countries is concentrated in a limited number of countries.

- Concentration of Egyptian Exports to Nile Basin Countries revealed that Sudan and Kenya are the main importers of Egyptian exports of (sugar and sugar confectionary, fruits and edible fruits, miscellaneous food preparations, vegetables and fruits preparations and parts); whereas Eritrea is the main importer of (plant and animal greases, fats, oils and waxes, milling products, malt and starches Grain, flour and starch preparations).

- As for imports from Nile Basin countries, Kenya is the main country from which Egypt imports tea, coffee and tobacco; Sudan and Ethiopia are the two main countries from which Egypt imports live animals and oilseeds; and finally, Sudan is the main country from which Egypt imports cotton. 
- Export similarity index for agricultural commodities traded between Egypt and Nile Basin countries reached $18.63 \%$, indicating that the structure of exports between the two parties is more integrated. On the other hand, the index showed high values regarding exports between Egypt and each of Uganda, Kenya and Tanzania, indicating that the structure of exports between Egypt and each of the mentioned countries is more competitive, thus scope for trade creation is wide.

- Trade compatibility index showed a high value for exports agricultural commodities and products traded between Egypt and Nile basin countries over the period 2008-2016 (sugar; fruits; plant and animal greases, fats, oils and waxes; gum and varnishes and vegetable extracts; vegetables and fruits preparations and parts; grinder Products, and grain starch; grain, flour and starch preparations) than Egyptian imports of the same commodities, indicating transformation of trade in Egyptian agricultural commodities at the account of agricultural commodities and products Nile Basin countries import from other countries to a degree higher than substituting agricultural commodities and products from Nile Basin countries by those imported by Egypt from other countries.

- There exists a notable improve in Nile Basin countries markets' competence to absorb Egyptian exports, total or agricultural, where Compassing Competence index amounted to $71.14 \%$ and $55.15 \%$, respectively.

In the light of the achieved results, the research offers the following

\section{recommendations:}

- Egyptian Commercial Representation Offices in Nile Basin countries should devote more attention to providing promising investment opportunities and logistics database to serve the purpose of trade exchange.

- Devoting high attention to introducing Egyptian agricultural commodities to Nile Basin countries with which trade exchange with Egypt is low, like Congo, Ruanda and Burundi, in addition to establishing joint agricultural projects to activate trade exchange between both parties.

- Singing mutual preferential agreements between Egypt and each of the member countries in the Nile Basin agreement to activate trade exchange between the two parties.

- Devoting high attention to increasing geographic and commodity concentration in both directions, Egyptian and African, with special focus on Ethiopia, Tanzania, Ruanda and Burundi.

- Devoting high attention to the development of production systems in Egypt to produce value-added and diversified products for the invasion of African markets with a focus on deep-industry products, including agro-processing of all kinds, types and commodities, which leads to the expansion of the market and increase trade returns.

\section{Reference}

1- الجهاز المركزى للتعبئة العامة والاحصاء، النشرة السنوية للتبادل التجارى بين مصر ودول حوض النيل، أعداد متفرقة. 
r- سمر أثرف الثشتاوى، "دراسة إقتصادية للتجارة الخارجية الزراعية مع دول حوض النيل"، رسالة

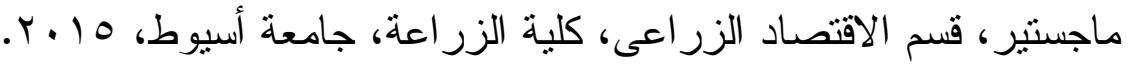

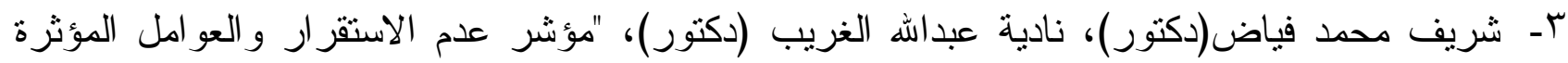

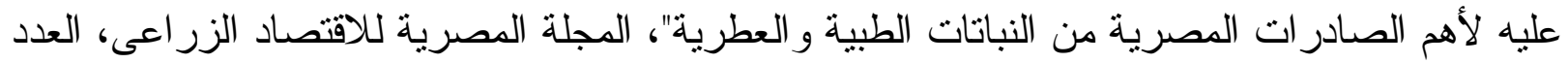
.r...V،

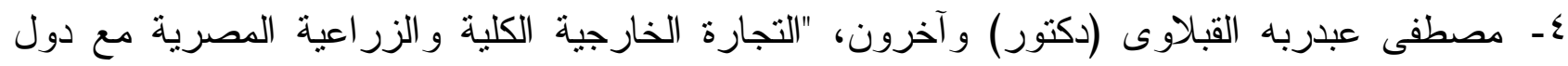

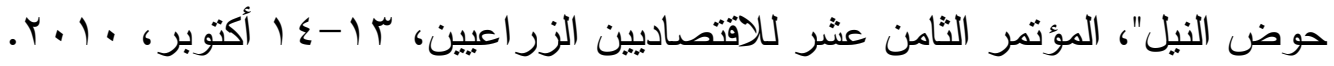

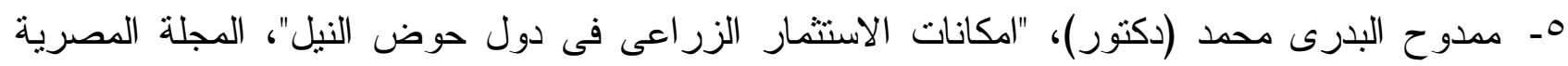

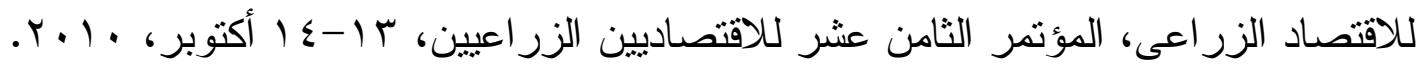

6- G. Erlat, S. Ekmen "Export Similarity and competitiveness: the case of turkey in the EU market", Anadolu International Conference in Economics', Turkey, 17-19 June, 2009.

7- J. M. Finger, M. E. Kreinin," A Measure of Export Similarity and Its Possible Uses", The Economic Journal, Vol. 89, No. 356 (December, 1979), pp. 905-912.

8- Trade Map "Trade Statistics for International Business Development", www.trademap.org

9- T. Fundira "An analysis of Africa's export performance and export similarity for select countries within the Tripartite Free Trade Area market" tralac trade law center, July 2013.

10- UNECA, assessing regional integration in Africa: Enhancing Intra-African Trade, Addis Ababa: Economic Commission for Africa, 2010.

11- United Nations, "International Trade Statistics database" Statistics Division: http://unstats.un.org/unsd/comtrade/db.

(*) Molasses resulting from the extraction or refining of sugar; Sugar confectionery not containing cocoa, incl. white chocolate; Other sugars, incl. chemically pure lactose, maltose, glucose and fructose, in solid form.

( $\Delta$ Prepared edible fats. Fats of bovine animals, sheep or goats (excluding oil and oleostearin). Other animal fats and oils and their fractions, whether or not refined, but not chemically.

(घ) Cotton, neither carded nor combed, Cotton sewing thread, Cotton yarn other than sewing thread, Cotton yarn put up for retail sale (excluding sewing thread). Woven fabrics of cotton. Cotton yarn put up for retail sale (excluding sewing thread). 


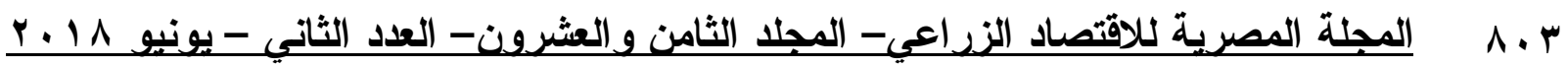


Table (2): Geographical distribution between Egypt and Nile Basin countries at (\$ million) during 1994-2016.

\begin{tabular}{|c|c|c|c|c|c|c|}
\hline \multirow{2}{*}{ Country } & \multicolumn{3}{|c|}{ Total trade } & \multicolumn{3}{c|}{ Agricultural trade } \\
\cline { 2 - 7 } & $\begin{array}{c}\text { Total } \\
\text { trade }\end{array}$ & $\begin{array}{c}\text { Total } \\
\text { exports }\end{array}$ & $\begin{array}{c}\text { Total } \\
\text { imports }\end{array}$ & $\begin{array}{c}\text { Total } \\
\text { trade }\end{array}$ & $\begin{array}{c}\text { Total } \\
\text { exports }\end{array}$ & $\begin{array}{c}\text { Total } \\
\text { imports }\end{array}$ \\
\hline Sudan & 300.03 & 254.03 & 46.00 & 98.55 & 80.97 & 17.59 \\
\hline Ethiopia & 48.11 & 30.77 & 17.33 & 19.64 & 6.59 & 13.06 \\
\hline Uganda & 19.80 & 16.44 & 3.36 & 6.85 & 4.67 & 2.17 \\
\hline Congo & 16.34 & 8.37 & 7.97 & 4.13 & 3.93 & 0.20 \\
\hline Kenya & 242.34 & 99.88 & 142.47 & 199.82 & 35.56 & 164.26 \\
\hline Tanzania & 17.75 & 14.11 & 3.64 & 5.93 & 4.82 & 1.11 \\
\hline Ruanda & 7.47 & 6.71 & 0.76 & 3.62 & 3.23 & 0.38 \\
\hline Burundi & 4.55 & 4.31 & 0.24 & 2.96 & 2.72 & 0.24 \\
\hline Eritrea & 22.42 & 20.88 & 1.54 & 16.00 & 14.13 & 1.87 \\
\hline Total & 678.81 & 455.51 & 223.30 & 357.51 & 156.62 & 200.89 \\
\hline
\end{tabular}

Source: Central Agency for Public Mobilization and statistics (CAPMAS).

\section{دراسة اقتصادية لتجارة مصر الزراعية فى ضوء مبادرة دول حوض النيل \\ عصام محمد زكى

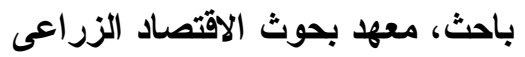

(الملخص

تجدد الاهتمام فى الاونة الاخيرة بتتمية العلاقات التجارية بين مصر و الدول الافريقية وتطوير اليات

للتعاون الاقتصادى المصرى الافريقى، و التى باتت تحتم السعى نحو نوثيق التبادل التجارى بين مصر ودول

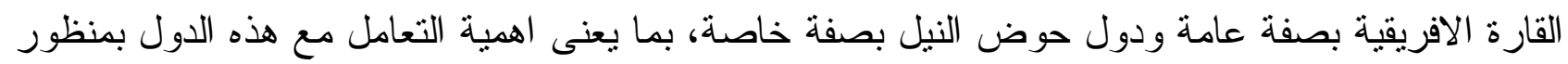
استر اتيجى شامل يعتمد على ربط المصالح المشتركة لدول حوض النيل سواء فى صوضئ صورة اتفاقيات ثنائية أو جماعية متل مبادرة حوض النيل فبر اير 1999 (Nile Basin Initiative) و التى تم النوقيع عليها بين دول حوض النيل العشر، إلا أنه على الرغم من كثرة عدد الدول المنضمة لمبادرة حوض النيل، وما تتنجه تلكي

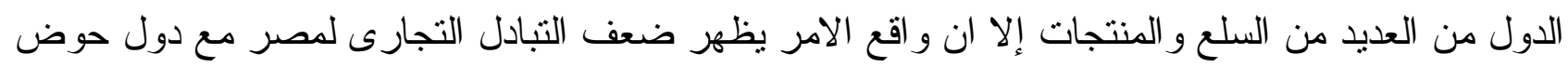

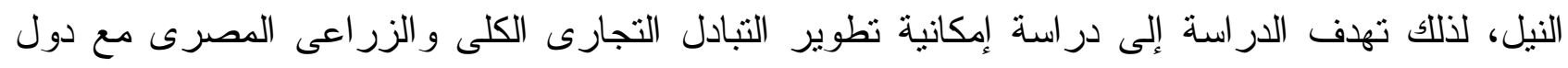

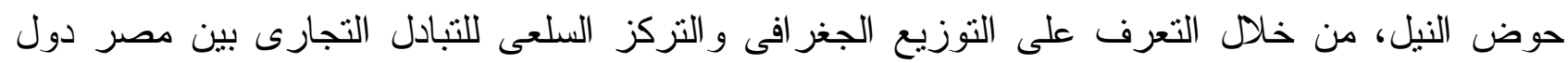

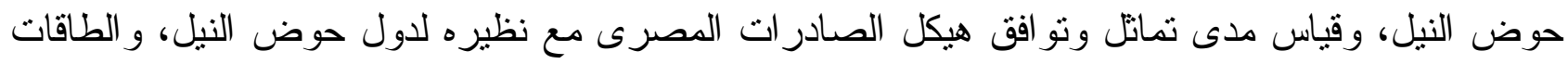
الاستعابية لاسواق دول حوض النيل لصادر ات مصر • وكانت النتائج كالتالى: - تز ايد الأهمية النسبية لقيمة التجارة الكلية المصرية دع دولئل دول حوض النيل للتجارة الكلية المصرية بمعدل

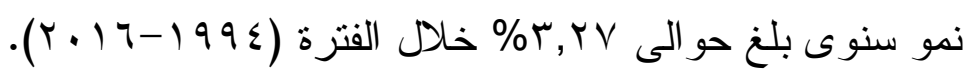


- تز ايد الأهمية النسبية لقيمة الصادرات الكلية المصرية مع دول حوض النيل للصادرات الكلية المصرية

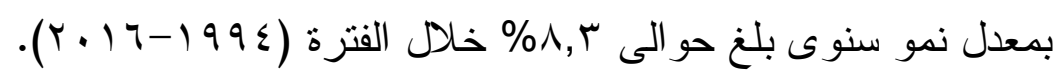

- تز ايد الأهمية النسبية لقيمة التجارة الزر اعية المصرية مع دول حوض النيل للتجارة الزر اعية المصرية

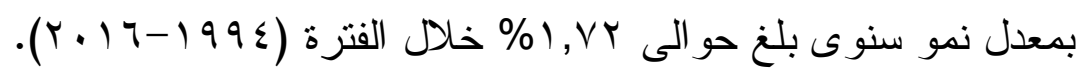

- تز ايد الأهمية النسبية لقيمة الصادرات الزراعية المصرية مع دول حوض النيل للصادرات الزراعية

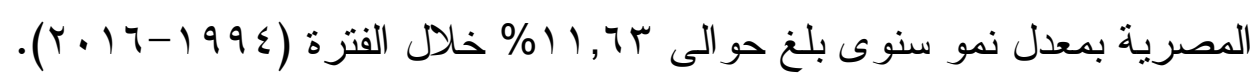

- بدر اسة التوزيع الجغر افى للصادر ات الزراعية المصرية مع دول حوض النيل تبين استحو اذ كل من

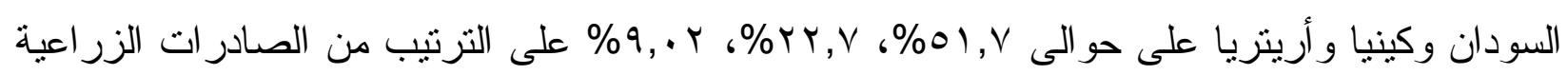
المصرية الموجهة إلى دول حوض النيل، وبلغ معامل جينى للتركز الجغر افى حو الى لV,T مما يشير إلى تركز الصادر ات الزر اعية المصرية فى عدد محدود من دول حوض النيل.

- بدر اسة التوزيع الجغر افى للواردات الزراعية المصرية مع دول حوض النيل تبين أن كينيا والسودان

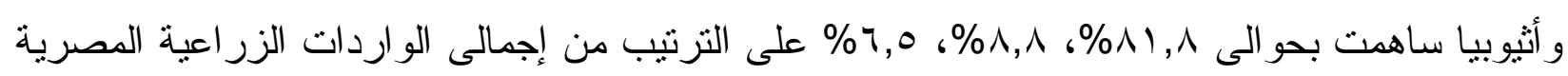
من دول حوض النيل، وبلغ معامل جينى للتركز الجغر افى حوالى مr,0 مما يشير إلى تركز الواردات الزر اعية المصرية فى عدد محدود من دول حوض النيل.

- بدر اسة التركز السلعى للصادر ات الزر اعية المصرية مع دول حوض النيل يتضح أن السودان، كينيا تعتبر الثريك (المستورد) الأساسى للصادر ات السلعية المصرية لكل من (السكر و المصنعات السكرية، و الفاكهة و الثمار الصالحة للأكل، ومحضر ات غذائية متتوعة، ومحضر ات خضر وفاكهة واجز ائها)، كما تعتبر أريتريا (المستورد) الأساسى للصادرات السلعية المصرية من (الشحوم والدهون النباتية والحيوانية، منتجات مطاحن ونشا حبوب، ومحضر ات حبوب ودقيق ونشا). - بدر اسة التزكز السلعى للواردات الزراعية المصرية مع دول حوض النيل تبين تزكز واردات البن و الثناى، و التبغ من كينيا، ونزكز واردات مصر من كل من الحيوانات الحية، و البذور الزيتية من كل من الدولتين السودان، و اثيوبيا. أما الواردات المصرية دن المنتجات القطنية فكانت السودان المصدر الرئيسى

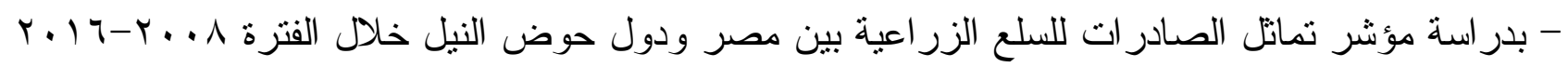

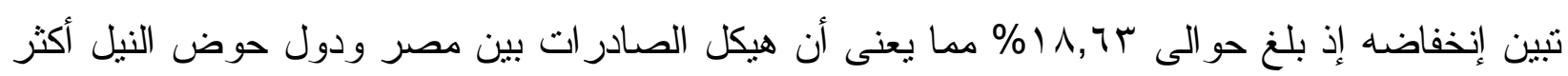
تكاملاً، و على الجانب الأخر ارتفع مؤشر تماثل الصادر ات بين مصر وكل من أو غندا، كينيا، نتز انيا مما يدل على أن هيكل الصادر ات بينهما أكثر تتافساً مما يعنى تشابه وتماثل هيكل الصادر ات بين مصر وهذه الدول وبالتالى هنالك فرصة لخلق التجارة بينهما.

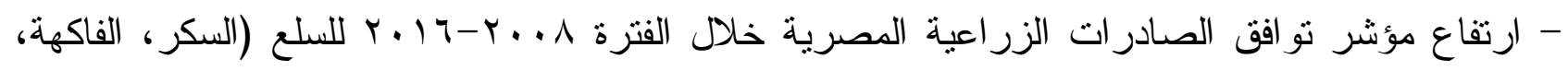
و الزيوت و الدهون النباتية و الحيو انية، الصمغ النباتى، والخضر و الفاكهة المجزة، الصناعات الغذائية

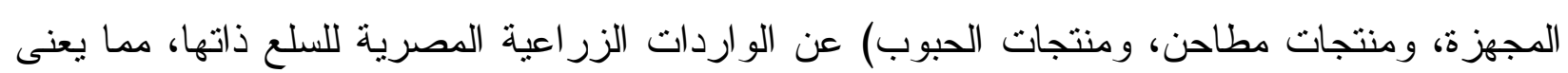




\section{Trade in the Context of Nile Basin's Initiative}

احتمال حدوث تحويل التجارة للسلع الزراعية المصرية على حساب السلع والمنتجات الزراعية التى

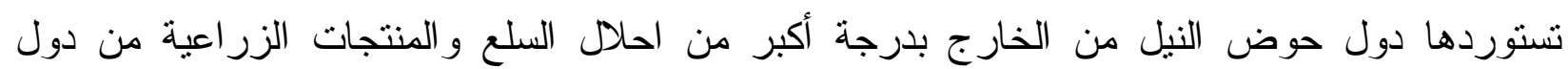

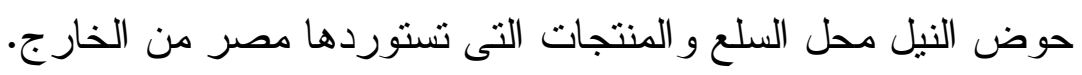

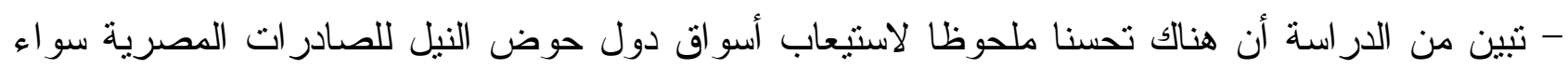

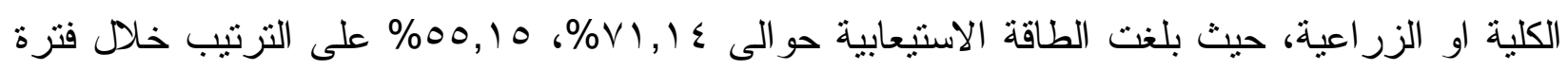
الار اسة.

وفى ضوء ما سبق توصى بالاتى:

- زيادة اهتمام مكاتب التمثيل التجارى المصرية بدول حوض النيل فى توفير الفرص الاستثمارية الواعدة

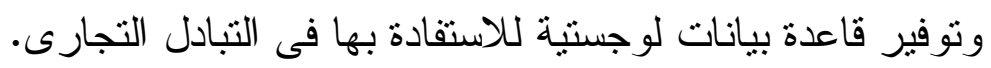

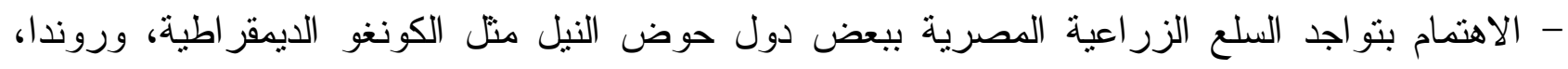

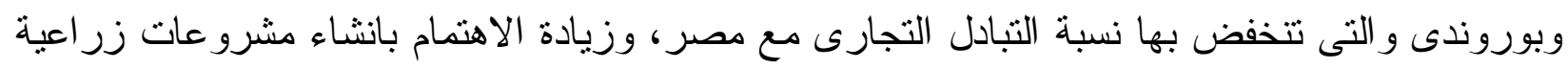
مشتركة من شأنها تتشيط التبادل التجارى معها. - عقد اتفاقيات نبادلية تفضيلية مشتركة بين الحكومة المصرية وحكومات دول حوض النبل كل على حدة لتنشيط التبادل التجارى.

- ضرورة الاهتمام بزيادة التبادل الجغر افي و السلعي فى الاتجاهين المصرى و الافريقى وخاصة دول أثيوبيا، وتنز انيا، وروندا، وبوروندى.

- ضرورة تطوير نظم الاتتاج فى مصر لانتاج منتجات ذات قيمة مضافة ومتتوعة لغزو الأسواق الأفريقية

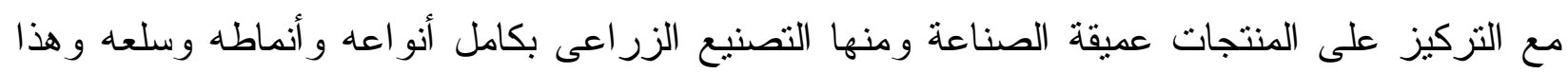
يؤدى إلى اتساع السوق وتزيد عو ائد التجارة. 